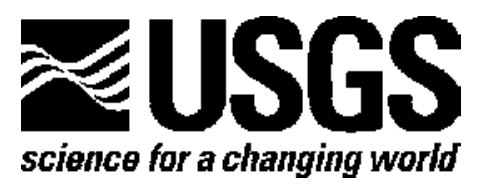

\title{
Publications of the Volcano Hazards Program 2010
}

By Manuel Nathenson

Open-File Report 2012-1177

U.S. Department of the Interior U.S. Geological Survey 


\section{U.S. Department of the Interior \\ KEN SALAZAR, Secretary}

\section{U.S. Geological Survey \\ Marcia K. McNutt, Director}

U.S. Geological Survey, Reston, Virginia: 2012

For product and ordering information:

World Wide Web: http://www.usgs.gov/pubprod

Telephone: 1-888-ASK-USGS

For more information on the USGS-the Federal source for science about the Earth,

its natural and living resources, natural hazards, and the environment:

World Wide Web: http://www.usgs.gov

Telephone: 1-888-ASK-USGS

Suggested citation:

Nathenson, Manuel, 2012, Publications of the Volcano Hazards Program 2010: U.S. Geological

Survey Open-File Report 2012-1177, 14 p. (Available at http://pubs.usgs.gov/of/2012/1177/.)

Any use of trade, product, or firm names is for descriptive purposes only and does not imply endorsement by the U.S. Government.

Although this report is in the public domain, permission must be secured from the individual copyright owners to reproduce any copyrighted material contained within this report. 


\section{Publications of the Volcano Hazards Program 2010}

By Manuel Nathenson

The Volcano Hazards Program of the U.S. Geological Survey (USGS) is part of the Geologic Hazards Assessments subactivity as funded by Congressional appropriation. Investigations are carried out in the USGS and with cooperators at the Alaska Division of Geological and Geophysical Surveys, University of Alaska Fairbanks Geophysical Institute, University of Hawaii Manoa and Hilo, University of Utah, and University of Washington Geophysics Program. This report lists publications from all these institutions. Only published papers and maps are included here; numerous abstracts presented at scientific meetings are omitted. Publication dates are based on year of issue, with no attempt to assign them to fiscal year. 


\section{Volcano Hazards Bibliography 2010}

Addison, J.A., Beget, J.E., Ager, T.A., and Finney, B.P., 2010, Marine tephrochronology of the Mt. Edgecumbe Volcanic Field, Southeast Alaska, USA: Quaternary Research, v. 73, p. 277-292.

Adleman, J.N., Cameron, C.E., Snedigar, S.F., Neal, C.A., and Wallace, K.L., 2010, Public outreach and communications of the Alaska Volcano Observatory during the 20052006 eruption of Augustine Volcano, chap. 27 of Power, J.A., Coombs, M.L., and Freymueller, J.T., eds., The 2006 eruption of Augustine Volcano, Alaska: U.S. Geological Survey Professional Paper 1769, p. 631-644. (Also available at http://pubs.usgs.gov/pp/1769/.)

Anderson, K., Lisowski, M., and Segall, P., 2010, Cyclic ground tilt associated with the 2004-2008 eruption of Mount St. Helens: Journal of Geophysical Research, v. 115, B11201, 29 p., doi:10.1029/2009JB007102.

Arnoult, K.M., Olson, J.V., Szuberla, C.A.L., McNutt, S.R., Garcés, M.A., Fee, David, and Hedlin, M.A.H., 2010, Infrasound observations of the 2008 explosive eruptions of Okmok and Kasatochi volcanoes, Alaska, in Ghan, S., and Carns, S., eds., The 2008 eruptions of Okmok and Kasatochi volcanoes, Alaska: Journal of Geophysical Research, v. 115, D00L15, 12 p., doi:10.1029/2010JD013987.

Bacon, C. R., Ramsey, D. W., Dutton, D. R., and Nimz, Kathryn, 2010, Geologic map of Mount Mazama and Crater Lake caldera, Oregon: ESRI Map Book, v. 25, p. 86-87.

Bailey, J.E., Dean, K.G., Dehn, Jonathan, and Webley, P.W., 2010, Integrated satellite observations of the 2006 eruption of Augustine Volcano, chap. 20 of Power, J.A., Coombs, M.L., and Freymueller, J.T., eds., The 2006 eruption of Augustine Volcano, Alaska: U.S. Geological Survey Professional Paper 1769, p. 481-506. (Also available at http://pubs.usgs.gov/pp/1769/.)

Ball, J.W., McCleskey, R.B., and Nordstrom, D.K., 2010, Water-chemistry data for selected springs, geysers, and streams in Yellowstone National Park, Wyoming, 20062008: U.S. Geological Survey Open-File Report 2010-1192, 109 p., available at http://pubs.usgs.gov/of/2010/1192/.

Begét, J.E., 2010, Characterizing pyroclastic-flow interactions with snow and water using environmental magnetism at Augustine Volcano, chap. 11 of Power, J.A., Coombs, M.L., and Freymueller, J.T., eds., The 2006 eruption of Augustine Volcano, Alaska: U.S. Geological Survey Professional Paper 1769, p. 269-283. (Also available at http://pubs.usgs.gov/pp/1769/.)

Biggs, Juliet, Lu, Zhong, Fournier, Tom, and Freymueller, J.T., 2010, Magma flux at Okmok Volcano, Alaska, from a joint inversion of continuous GPS, campaign GPS, and interferometric synthetic aperture radar: Journal of Geophysical Research, v. 115, B12401, 11 p., doi:10.1029/2010JB007577.

Buurman, Helena, and West, M.E., 2010, Seismic precursors to volcanic explosions during the 2006 eruption of Augustine Volcano, chap. 2 of Power, J.A., Coombs, M.L., and Freymueller, J.T., eds., The 2006 eruption of Augustine Volcano, Alaska: U.S. Geological Survey Professional Paper 1769, p. 41-57. (Also available at http://pubs.usgs.gov/pp/1769/.) 
Cahill, C.F., Rinkleff, P.G., Dehn, Jonathan, Webley, P.W., Cahill, T.A., and Barnes, D.E., 2010, Aerosol measurements from a recent Alaskan volcanic eruption: Implications for volcanic ash transport predictions: Journal of Volcanology and Geothermal Research, v. 198, p. 76-80.

Cervelli, P.F., Fournier, T.J., Freymueller, J.T., Power, J.A., Lisowski, Michael, and Pauk, B.A., 2010, Geodetic constraints on magma movement and withdrawal during the 2006 eruption of Augustine Volcano, chap. 17 of Power, J.A., Coombs, M.L., and Freymueller, J.T., eds., The 2006 eruption of Augustine Volcano, Alaska: U.S. Geological Survey Professional Paper 1769, p. 427-452. (Also available at http://pubs.usgs.gov/pp/1769/.)

Chang, Wu-Lung, Smith, R.B., Farrell, Jamie, and Puskas, C.M., 2010, An extraordinary episode of Yellowstone caldera uplift, 2004-2010, from GPS and InSAR observations: Geophysical Research Letters, v. 37, L23302, 6 p., doi:10.1029/2010GL045451.

Chouet, B.A., Dawson, P.B., James, M.R., and Lane, S.J., 2010, Seismic source mechanism of degassing bursts at Kilauea Volcano, Hawaii-Results from waveform inversion in the 10-50 s band: Journal of Geophysical Research, v. 115, B09311, 24 p., doi:10.1029/2009JB006661.

Claiborne, L.L., Miller, C.F., Flanagan, D.M., Clynne, M.A., and Wooden, J.L., 2010, Zircon reveals protracted magma storage and recycling beneath Mount St. Helens: Geology, v. 38, p. 1011-1014.

Clynne, M.A., and Muffler, L.J.P., 2010, Geologic map of Lassen Volcanic National Park and vicinity, California: U.S. Geological Survey Scientific Investigations Map 2899, 116 p., 3 plates, scale 1:50,000, CD-ROM. (Also available at http://pubs.usgs.gov/sim/2899/.)

Coombs, M.L., Bull, K.F., Vallance, J.W., Schneider, D.J., Thoms, E.E., Wessels, R.L., and McGimsey, R.G., 2010, Timing, distribution, and volume of proximal products of the 2006 eruption of Augustine Volcano, chap. 8 of Power, J.A., Coombs, M.L., and Freymueller, J.T., eds., The 2006 eruption of Augustine Volcano, Alaska: U.S. Geological Survey Professional Paper 1769, p. 145-185, 1 plate, scale 1:20,000. (Also available at http://pubs.usgs.gov/pp/1769/.)

Dawson, P.B., Benítez, M.C., Chouet, B.A., Wilson, David, and Okubo, P.G., 2010, Monitoring very-long-period seismicity at Kilauea Volcano, Hawaii: Geophysical Research Letters, v. 37, L18306, 6 p., doi:10.1029/2010GL044418.

DeGange, Anthony, 2010, U.S. Geological Survey (USGS) Western Region-Kasatochi Volcano coastal and ocean science: U.S. Geological Survey Fact Sheet 2010-3028, 2 p. (Also available at http://pubs.usgs.gov/fs/2010/3028/.)

DeGange, A.R., Byrd, G.V., Walker, L.R., and Waythomas, C.F., 2010, Introduction-The impacts of the 2008 eruption of Kasatochi Volcano on terrestrial and marine ecosystems in the Aleutian Islands, Alaska, in Special section-Impacts of the 2008 volcanic eruption on the terrestrial and nearshore marine ecosystems of Kasatochi Island, Alaska: Arctic, Antarctic, and Alpine Research, v. 42, p. 245-249.

Denlinger, R.P., and O'Connell, D.R.H., 2010, Simulations of cataclysmic outburst floods from Pleistocene Glacial Lake Missoula: Geological Society of America Bulletin, v. 122 , p. 678-689. 
DeShon, H.R., Thurber, C.H., and Power, J.A., 2010, Earthquake waveform similarity and evolution at Augustine Volcano from 1993 to 2006, chap. 5 of Power, J.A., Coombs, M.L., and Freymueller, J.T., eds., The 2006 eruption of Augustine Volcano, Alaska: U.S. Geological Survey Professional Paper 1769, p. 103-118. (Also available at http://pubs.usgs.gov/pp/1769/.)

Dixon, J.P., Stihler, S.D., Power, J.A., and Searcy, C.K., 2010, Catalog of earthquake hypocenters at Alaskan volcanoes: January 1 through December 31, 2009: U.S. Geological Survey Data Series 531, 84 p., data files, available at http://pubs.usgs.gov/ds/531/.

Donnelly-Nolan, J.M., 2010, Geologic map of Medicine Lake volcano, northern California: U.S. Geological Survey Scientific Investigations Map 2927, 48 p., 2 plates, scale 1:50,000, CD-ROM. (Also available at http://pubs.usgs.gov/sim/2927/.)

Drew, G.S., Dragoo, D.E., Renner, Martin, and Piatt, J.F., 2010, At-sea observations of marine birds and their habitats before and after the 2008 eruption of Kasatochi Volcano, Alaska, in Special section-Impacts of the 2008 volcanic eruption on the terrestrial and nearshore marine ecosystems of Kasatochi Island, Alaska: Arctic, Antarctic, and Alpine Research, v. 42, p. 325-334.

Driedger, Carolyn, Westby, Liz, Faust, Lisa, Frenzen, Peter, Bennett, Jeanne, and Clynne, Michael, 2010, 30 cool facts about Mount St. Helens: U.S. Geological Survey General Information Product 103, 1 plate. (Also available at http://pubs.usgs.gov/gip/103/.)

Eichelberger, John, 2010, Messy magma mixtures: Nature Geoscience, v. 3, p. 593-594. Evans, W.C., Bergfeld, Deborah, McGeehin, J.P., King, J.C., and Heasler, Henry, 2010, Tree-ring ${ }^{14} \mathrm{C}$ links seismic swarm to $\mathrm{CO}_{2}$ spike at Yellowstone, USA: Geology, v. 38, p. 1075-1078.

Evans, W.C., Mariner, R.H., Bergfeld, D., Revesz, K.M., and McGeehin, J.P., 2010, Carbon isotope composition of $\mathrm{CO}_{2}$ at Cascade Arc volcanoes, in Birkle, Peter, and Torres-Alvarado, I.S., eds., Water-Rock Interaction, $13^{\text {th }}$ International Conference on Water-Rock Interaction, Proceedings: Guanajuato, Mexico, August 16-20, 2010, London, CRC Press, p. 195-198.

Farrar, Christopher, DeAngelo, Jacob, Williams, Colin, Grubb, Frederick, and Hurwitz, Shaul, 2010, Temperature data from wells in Long Valley Caldera, California: U.S. Geological Survey Data Series 523, data files, available at http://pubs.usgs.gov/ds/523/.

Farrell, Jamie, Smith, R.B., Taira, Taka'aki, Chang, Wu-Lung, and Puskas, C.M., 2010, Dynamics and rapid migration of the energetic 2008-2009 Yellowstone Lake earthquake swarm: Geophysical Research Letters, v. 37, L19305, 5 p., doi:10.1029/2010GL044605.

Fee, David, Garcés, Milton, Patrick, Matt, Chouet, Bernard, Dawson, Phil, and Swanson, Don, 2010, Infrasonic harmonic tremor and degassing bursts from Halema'uma'u Crater, Kilauea Volcano, Hawaii: Journal of Geophysical Research, v. 115, B11316, 15 p., doi:10.1029/2010JB007642.

Fisher, M.A., Ruppert, N.A., White, R.A., Sliter, R.W., and Wong, F.L., 2010, Distal volcano-tectonic seismicity near Augustine Volcano, chap. 6 of Power, J.A., Coombs, M.L., and Freymueller, J.T., eds., The 2006 eruption of Augustine Volcano, Alaska: U.S. Geological Survey Professional Paper 1769, p. 119-128. (Also available at http://pubs.usgs.gov/pp/1769/.) 
Freymueller, J.T., and Kaufman, A.M., 2010, Changes in the magma system during the 2008 eruption of Okmok volcano, Alaska, based on GPS measurements: Journal of Geophysical Research, v. 115, B12415, 14 p., doi:10.1029/2010JB007716.

Greene, A.R., Garcia, M.O., Weis, Dominique, Ito, Garrett, Kuga, Maia, Robinson, Joel, and Yamasaki, Seiko, 2010, Low-productivity Hawaiian volcanism between Kaua'i and O‘ahu: Geochemistry Geophysics Geosystems, v. 11, Q0AC08, 30 p., doi:10.1029/2010GC003233.

Guffanti, Marianne, Casadevall, T.J., and Budding, Karin, 2010, Encounters of aircraft with volcanic ash clouds; A compilation of known incidents, 1953-2009: U.S. Geological Survey Data Series 545, 12 p., data files, available at http://pubs.usgs.gov/ds/545/.

Guffanti, Marianne, Diefenbach, A.K., Ewert, J.W., Ramsey, D.W., Cervelli, P.F., and Schilling, S.P., 2010, Volcano-monitoring instrumentation in the United States, 2008: U.S. Geological Survey Open-File Report 2009-1165, 32 p., database, available at http://pubs.usgs.gov/of/2009/1165.

Guffanti, Marianne, Schneider, D.J., Wallace, K.L., Hall, Tony, Bensimon, D.R., and Salinas, L.J., 2010, Aviation response to a widely dispersed volcanic ash and gas cloud from the August 2008 eruption of Kasatochi, Alaska, USA, in Ghan, S., and Carns, S., eds., The 2008 eruptions of Okmok and Kasatochi volcanoes, Alaska: Journal of Geophysical Research, v. 115, D00L19, 9 p., doi:10.1029/2010JD013868.

Hamme, R.C., Webley, P.W., Crawford, W.R., Whitney, F.A., DeGrandpre, M.D., Emerson, S.R., Eriksen, C.C., Giesbrecht, K.E., Gower, J.F.R., Kavanaugh, M.T., Peña, M.A., Sabine, C.L., Batten, S.D., Coogan, L.A., Grundle, D.S., and Lockwood, Deidre, 2010, Volcanic ash fuels anomalous plankton bloom in subarctic northeast Pacific: Geophysical Research Letters, v. 37, L19604, 5 p., doi:10.1029/2010GL044629.

Haney, M.M., 2010, Location and mechanism of very long period tremor during the 2008 eruption of Okmok Volcano from interstation arrival times, in Ghan, S., and Carns, S., eds., The 2008 eruptions of Okmok and Kasatochi volcanoes, Alaska: Journal of Geophysical Research, v. 115, B00B05, 13 p., doi:10.1029/2010JB007440.

Hanyu, Takeshi, Kimura, Jun-Ichi, Katakuse, Maiko, Calvert, A.T., Sisson, T.W., and Nakai, Shun'ichi, 2010, Source materials for inception stage Hawaiian magmas: $\mathrm{Pb}-\mathrm{He}$ isotope variations for early Kilauea: Geochemistry Geophysics Geosystems, v. 11, Q0AC01, 25 p., doi:10.1029/2009GC002760.

Helz, R.T., and Taggart, J.E., Jr., 2010, Whole-rock analyses of core samples from the 1988 drilling of Kilauea Iki lava lake, Hawaii: U.S. Geological Survey Open-File Report 2010-1093, 47 p., available at http://pubs.usgs.gov/of/2010/1093/.

Hildreth, Wes, Godoy, Estanislao, Fierstein, Judy, and Singer, Brad, 2010, Laguna del Maule volcanic field-Eruptive history of a Quaternary basalt-to-rhyolite distributed volcanic field on the Andean rangecrest in central Chile: Servicio Nacional de Geología y Minería - Chile Boletín 63, 145 p.

Hill, D.P., 2010, Surface-wave potential for triggering tectonic (non-volcanic) tremor: Bulletin of the Seismological Society of America, v. 100, p. 1859-1878.

Hurwitz, Shaul, Evans, W.C., and Lowenstern, J.B., 2010, River solute fluxes reflecting active hydrothermal chemical weathering of the Yellowstone Plateau Volcanic Field, USA: Chemical Geology, v. 276, p. 331-343. 
Hurwitz, Shaul, Farrar, C.D., and Williams, C.F., 2010, The thermal regime in the resurgent dome of Long Valley Caldera, California: Inferences from precision temperature logs in deep wells: Journal of Volcanology and Geothermal Research, v. 198, p. 233-240.

Ingebritsen, S.E., 2010, Book review-Geological fluid dynamics-Sub-surface flow and reactions; by Owen W. Phillips: American Journal of Science, v. 310, p. 128-129.

Ingebritsen, S.E., Geiger, S., Hurwitz, S., and Driesner, T., 2010, Numerical simulation of magmatic hydrothermal systems: Reviews of Geophysics, v. 48, RG1002, 33 p., doi:10.1029/2009RG000287.

Ingebritsen, S.E., and Manning, C.E., 2010, Permeability of the continental crustDynamic variations inferred from seismicity and metamorphism: Geofluids, v. 10, p. 193-205.

Ingebritsen, S.E., and Mariner, R.H., 2010, Hydrothermal heat discharge in the Cascade Range, northwestern United States: Journal of Volcanology and Geothermal Research, v. 196, p. 208-218.

Iverson, N.R., Mann, J.E., and Iverson, R.M., 2010, Effects of soil aggregates on debrisflow mobilization-Results from ring-shear experiments: Engineering Geology, v. 114, p. 84-92.

Iverson, R.M., Logan, Matthew, LaHusen, R.G., and Berti, Mateo, 2010, The perfect debris flow? Aggregated results from 28 large-scale experiments: Journal of Geophysical Research, v. 115, F03005, 29 p., doi:10.1029/2009JF001514.

Jacobs, K.M., and McNutt, S.R., 2010, Using seismic $b$-values to interpret seismicity rates and physical processes during the preeruptive earthquake swarm at Augustine Volcano 2005-2006, chap. 3 of Power, J.A., Coombs, M.L., and Freymueller, J.T., eds., The 2006 eruption of Augustine Volcano, Alaska: U.S. Geological Survey Professional Paper 1769, p. 59-83. (Also available at http://pubs.usgs.gov/pp/1769/.)

Janik, C.J., and Bergfeld, Deborah, 2010, Analyses of gas, steam and water samples collected in and around Lassen Volcanic National Park, California, 1975-2002: U.S. Geological Survey Open-File Report, 2010-1036, 13 p., data files, available at http://pubs.usgs.gov/of/2010/1036/.

Janik, C.J., and McLaren, M.K., 2010, Seismicity and fluid geochemistry at Lassen Volcanic National Park, California: Evidence for two circulation cells in the hydrothermal system: Journal of Volcanology and Geothermal Research, v. 189, p. 257-277.

Jewett, S.C., Bodkin, J.L., Chenelot, Héloïse, Esslinger, G.G., and Hoberg, M.K., 2010, The nearshore benthic community of Kasatochi Island, one year after the 2008 volcanic eruption, in Special section-Impacts of the 2008 volcanic eruption on the terrestrial and nearshore marine ecosystems of Kasatochi Island, Alaska: Arctic, Antarctic, and Alpine Research, v. 42, p. 315-324.

Johnson, D.J., Eggers, A.A., Bagnardi, Marco, Battaglia, Maurizio, Poland, M.P., and Miklius, Asta, 2010, Shallow magma accumulation at Kīlauea Volcano, Hawai' ${ }^{\prime}$, revealed by microgravity surveys: Geology, v. 38, p. 1139-1142. 
Johnson, J.H., Prejean, Stephanie, Savage, M.K., and Townend, John, 2010, Anisotropy, repeating earthquakes, and seismicity associated with the 2008 eruption of Okmok volcano, Alaska, in Ghan, S., and Carns, S., eds., The 2008 eruptions of Okmok and Kasatochi volcanoes, Alaska: Journal of Geophysical Research, v. 115, B00B04, 21 p., doi:10.1029/2009JB006991.

Koch, R.D., Ramsey, D.W., Sherrod, D.R., Taylor, E.M., Ferns, M.L., Scott, W.E., Conrey, R.M., and Smith, G.A., 2010, Database for the geologic map of the Bend 30- X 60-Minute Quadrangle, central Oregon: U.S. Geological Survey Data Series 303, 1 CD-ROM, data files, available at http://pubs.usgs.gov/ds/303/.

Lalla, D.J., and Power, J.A., 2010, A two-step procedure for calculating earthquake hypocenters at Augustine Volcano, chap. 7 of Power, J.A., Coombs, M.L., and Freymueller, J.T., eds., The 2006 eruption of Augustine Volcano, Alaska: U.S. Geological Survey Professional Paper 1769, p. 129-142. (Also available at http://pubs.usgs.gov/pp/1769/.)

Larsen, J.F., Nye, C.J., Coombs, M.L., Tilman, Mariah, Izbekov, Pavel, and Cameron, Cheryl, 2010, Petrology and geochemistry of the 2006 eruption of Augustine Volcano, chap. 15 of Power, J.A., Coombs, M.L., and Freymueller, J.T., eds., The 2006 eruption of Augustine Volcano, Alaska: U.S. Geological Survey Professional Paper 1769, p. 335-382. (Also available at http://pubs.usgs.gov/pp/1769/.)

Larson, K.M., Poland, Michael, and Miklius, Asta, 2010, Volcano monitoring using GPS-Developing data analysis strategies based on the June 2007 Kilauea Volcano intrusion and eruption: Journal of Geophysical Research, v. 115, B07406, 10 p., doi:10.1029/2009JB007022.

Lee, Chang-Wook, Lu, Zhong, Jung, Hyung-Sup, Won, Joong-Sun, and Dzurisin, Daniel, 2010, Surface deformation of Augustine Volcano, 1992-2005, from multipleinterferogram processing using a refined small baseline subset (SBAS) interferometric synthetic aperture radar (InSAR) approach, chap. 18 of Power, J.A., Coombs, M.L., and Freymueller, J.T., eds., The 2006 eruption of Augustine Volcano, Alaska: U.S. Geological Survey Professional Paper 1769, p. 453-465. (Also available at http://pubs.usgs.gov/pp/1769/.)

Lehto, H.L., Roman, D.C., and Moran, S.C., 2010, Temporal changes in stress preceding the 2004-2008 eruption of Mount St. Helens, Washington: Journal of Volcanology and Geothermal Research, v. 198, p. 129-142.

Lu, Zhong, and Dzurisin, Daniel, 2010, Ground surface deformation patterns, magma supply, and magma storage at Okmok volcano, Alaska, from InSAR analysis - 2 . Coeruptive deflation, July-August 2008, in Ghan, S., and Carns, S., eds., The 2008 eruptions of Okmok and Kasatochi volcanoes, Alaska: Journal of Geophysical Research, v. 115, B00B03, 13 p., doi:10.1029/2009JB006970.

Lu, Zhong, Dzurisin, Daniel, Biggs, Juliet, Wicks, Charles, Jr., and McNutt, Steve, 2010, Ground surface deformation patterns, magma supply, and magma storage at Okmok volcano, Alaska, from InSAR analysis - 1. Intereruption deformation, 1997-2008, in Ghan, S., and Carns, S., eds., The 2008 eruptions of Okmok and Kasatochi volcanoes, Alaska: Journal of Geophysical Research, v. 115, B00B02, 14 p., doi:10.1029/2009JB006969. 
Lu, Zhong, Dzurisin, Daniel, Jung, Hyung-Sup, Zhang, Jixian, and Zhang, Yonghong, 2010, Radar image and data fusion for natural hazards characterization: International Journal of Image and Data Fusion, v. 1, p. 217-242.

Lu, Zhong, Zhang, Jixian, Zhang, Yonghong, and Dzurisin, Daniel, 2010, Monitoring and characterizing natural hazards with satellite InSAR imagery: Annals of GIS, v. 16, p. $55-66$.

Major, J.J., O'Connor, J.E., Podolak, C.J., Keith, K., Spicer, K.R., Wallick, J.R., Bragg, H.M., Pittman, Smokey, Wilcock, P.R., Rhode, Abagail, and Grant, G.E., 2010, Evolving fluvial response of the Sandy River, Oregon, following removal of Marmot Dam: Proceedings of the $9^{\text {th }}$ Federal Interagency Sedimentation Conference, Las Vegas, NV, June 27-July 1, 2010, 11 p.

Major, J.J., Spicer, K.R., and Collins, R.A., 2010, Time-lapse imagery of the breaching of Marmot Dam, Oregon, and subsequent erosion of sediment by the Sandy River, October 2007 to May 2008: U.S. Geological Survey Data Series 521, 5 p., movies, available at http://pubs.usgs.gov/ds/521/.

Masterlark, Timothy, Haney, Matthew, Dickinson, Haylee, Fournier, Tom, and Searcy, Cheryl, 2010, Rheologic and structural controls on the deformation of Okmok volcano, Alaska-FEMs, InSAR, and ambient noise tomography: Journal of Geophysical Research, v. 115, B02409, 22 p., doi:10.1029/2009JB006324.

McCleskey, R.B., Nordstrom, D.K., Susong, D.D., Ball, J.W., and Holloway, J.M., 2010, Source and fate of inorganic solutes in the Gibbon River, Yellowstone National Park, Wyoming, USA-I. Low-flow discharge and major solute chemistry: Journal of Volcanology and Geothermal Research, v. 193, p. 189-202.

McCleskey, R.B., Nordstrom, D.K., Susong, D.D., Ball, J.W., and Taylor, H.E., 2010, Source and fate of inorganic solutes in the Gibbon River, Yellowstone National Park, Wyoming, USA - II. Trace element chemistry: Journal of Volcanology and Geothermal Research, v. 196, p. 139-155.

McGee, K.A., Doukas, M.P., McGimsey, R.G., Neal, C.A., and Wessels, R.L., 2010, Emission of $\mathrm{SO}_{2}, \mathrm{CO}_{2}$, and $\mathrm{H}_{2} \mathrm{~S}$ from Augustine Volcano, 2002-2008, chap. 26 of Power, J.A., Coombs, M.L., and Freymueller, J.T., eds., The 2006 eruption of Augustine Volcano, Alaska: U.S. Geological Survey Professional Paper 1769, p. 609 627. (Also available at http://pubs.usgs.gov/pp/1769/.)

McNutt, S.R., Tytgat, Guy, Estes, S.A., and Stihler, S.D., 2010, A parametric study of the January 2006 explosive eruptions of Augustine Volcano, using seismic, infrasonic, and lightning data, chap. 4 of Power, J.A., Coombs, M.L., and Freymueller, J.T., eds., The 2006 eruption of Augustine Volcano, Alaska: U.S. Geological Survey Professional Paper 1769, p. 85-102. (Also available at http://pubs.usgs.gov/pp/1769/.)

Montgomery-Brown, E.K., Sinnett, D.K., Poland, Michael, Segall, Paul, Orr, Tim, Zebker, Howard, and Miklius, Asta, 2010, Geodetic evidence for en echelon dike emplacement and concurrent slow slip during the June 2007 intrusion and eruption at Kīlauea volcano, Hawaii: Journal of Geophysical Research, v. 115, B07405, 15 p., doi:10.1029/2009JB006658. 
Muffler, L.J.P., Robinson, J.E., Felger, T.J., Dutton, D.R., and Clynne, M.A., 2010, Database for the geologic map of Lassen Volcanic National Park and vicinity, California, in Clynne, M.A., and Muffler, L.J.P., Geologic map of Lassen Volcanic National Park and vicinity, California: U.S. Geological Survey Scientific Investigations Map 2899, scale 1:50,000, 1 CD-ROM. (Also available at http://pubs.usgs.gov/sim/2899/database.html.)

Nakata, J.S., and Okubo, P.G., 2010, Hawaiian Volcano Observatory seismic data, January to March 2009: U.S. Geological Survey Open-File Report 2010-1079, 47 p., available at http://pubs.usgs.gov/of/2010/1079/.

Nathenson, Manuel, 2010, Publications of the Volcano Hazards Program 2008: U.S. Geological Survey Open-File Report 2010-1052, 14 p., available at http://pubs.usgs.gov/of/2010/1052/.

Neal, C.A., and Guffanti, M.C., 2010, Airborne volcanic ash-A global threat to aviation: U.S. Geological Survey Fact Sheet 2010-3116, 6 p. (Also available at http://pubs.usgs.gov/fs/2010/3116/.)

Neal, C.A., Murray, T.L., Power, J.A., Adleman, J.N., Whitmore, P.M., and Osiensky, J.M., 2010, Hazard information management, interagency coordination, and impacts of the 2005-2006 eruption of Augustine Volcano, chap. 28 of Power, J.A., Coombs, M.L., and Freymueller, J.T., eds., The 2006 eruption of Augustine Volcano, Alaska: U.S. Geological Survey Professional Paper 1769, p. 645-667. (Also available at http://pubs.usgs.gov/pp/1769/.)

Nordstrom, D.K., McCleskey, R.B., Susong, D.D., Runkel, R.L., and Ball, J.W., 2010, Fate of thermal solutes for Gibbon and Firehole Rivers, Yellowstone National Park, USA, in Birkle, Peter, and Torres-Alvarado, I.S., eds., Water-Rock Interaction, $13^{\text {th }}$ International Conference on Water-Rock Interaction, Proceedings: Guanajuato, Mexico, August 16-20, 2010, London, CRC Press, p. 261-264.

Pallister, J.S., Major, J.J., Pierson, T.C., Hoblitt, R.P., Lowenstern, J.B., Eichelberger, J.C., Lara, Luis, Moreno, Hugo, Muñoz, Jorge, Castro, J.M., Iroumé, Andrés, Andreoli, Andrea, Jones, Julia, Swanson, Fred, and Crisafulli, Charlie, 2010, Interdisciplinary studies of eruption at Chaitén Volcano, Chile: Eos Transactions American Geophysical Union, v. 91, p. 381-382.

Pallister, J.S., McCausland, W.A., Jónsson, Sigurjón, Lu, Zhong, Zahran, H.M., El Hadidy, Salah, Aburukbah, Abdallah, Stewart, I.C.F., Lundgren, P.R., White, R.A., and Moufti, M.R.H., 2010, Broad accommodation of rift-related extension recorded by dyke intrusion in Saudi Arabia: Nature Geoscience, v. 3, p. 705-712.

Paskievitch, John, Read, Cyrus, and Parker, Thomas, 2010, Remote telemetered and timelapse cameras at Augustine Volcano, chap. 12 of Power, J.A., Coombs, M.L., and Freymueller, J.T., eds., The 2006 eruption of Augustine Volcano, Alaska: U.S. Geological Survey Professional Paper 1769, p. 285-293. (Also available at http://pubs.usgs.gov/pp/1769/.)

Patrick, M.R., Kauahikaua, J.P., and Antolik, Loren, 2010, MATLAB tools for improved characterization and quantification of volcanic incandescence in Webcam imagery: Applications at Kīlauea Volcano, Hawai'i: U.S. Geological Survey Techniques and Methods, book 13, chap. A1, 16 p., available at http://pubs.usgs.gov/tm/tm13a1/. 
Pauk, B.A., Jackson, Michael, Feaux, Karl, Mencin, David, and Bohnenstiehl, Kyle, 2010, The Plate Boundary Observatory permanent global positioning system network on Augustine Volcano before and after the 2006 eruption, chap. 19 of Power, J.A., Coombs, M.L., and Freymueller, J.T., eds., The 2006 eruption of Augustine Volcano, Alaska: U.S. Geological Survey Professional Paper 1769, p. 467-477. (Also available at http://pubs.usgs.gov/pp/1769/.)

Peng, Zhigang, Hill, D.P., Shelly, D.R., and Aiken, Chastity, 2010, Remotely triggered microearthquakes and tremor in central California following the $2010 M_{w} 8.8$ Chile earthquake: Geophysical Research Letters, v. 37, L24312, 6 p., doi:10.1029/2010GL045462.

Poland, Michael, 2010, Learning to recognize volcanic non-eruptions: Geology, v. 38, p. 287-288.

Poland, Michael, 2010, Localized surface disruptions observed by InSAR during strong earthquakes in Java and Hawai'i: Bulletin of the Seismological Society of America, v. 100 , p. 532-540.

Poland, Michael, Miklius, Asta, Wilson, David, Okubo, Paul, Montgomery-Brown, Emily, Segall, Paul, Brooks, Benjamin, Foster, James, Wolfe, Cecily, Syracuse, Ellen, and Thurber, Clifford, 2010, Slow slip event at Kîlauea Volcano: Eos Transactions of the American Geophysical Union, v. 91, p. 118-119.

Power, J.A., Coombs, M.L., and Freymueller, J.T., eds., 2010, The 2006 eruption of Augustine Volcano, Alaska: U.S. Geological Survey Professional Paper 1769, 667 p., 1 plate, scale 1:20,000, DVD. (Also available at http://pubs.usgs.gov/pp/1769/.)

Power, J.A., and Lalla, D.J., 2010, Seismic observations of Augustine Volcano, 19702007, chap. 1 of Power, J.A., Coombs, M.L., and Freymueller, J.T., eds., The 2006 eruption of Augustine Volcano, Alaska: U.S. Geological Survey Professional Paper 1769, p. 3-40. (Also available at http://pubs.usgs.gov/pp/1769/.)

Pringle, P.T., Pierson, T.C., Cameron, K.A., and Sheppard, P.R., 2010, Late Eighteenth Century Old Maid eruption and lahars at Mount Hood, Oregon (USA) dated with tree rings and historical observations, in Stoffel, Markus, Bollschweiler, Michelle, Butler, D.R., and Luckman, B.H., eds., Tree rings and natural hazards - A state-of-the-art: Advances in Global Change Research, v. 41, Heidelberg, Springer, p. 487-491.

Queija, V.R., 2010, Mount St. Helens lidar: U.S. Geological Survey General Information Product 116, 1 plate. (Also available at http://pubs.usgs.gov/gip/116/.)

Ramsey, D.W., Felger, T.J., Lougee, Ellen, Bruggman, P.E., and Donnelly-Nolan, J. M., 2010, Database for the geologic map of Medicine Lake volcano, northern California, in Donnelly-Nolan, J.M., Geologic map of Medicine Lake volcano, northern California: U.S. Geological Survey Scientific Investigations Map 2927, scale 1:50,000, CD-ROM. (Also available at http://pubs.usgs.gov/sim/2927/.)

Reid, M.E., Brien, D.L., and Waythomas, C.F., 2010, Preliminary slope-stability analysis of Augustine Volcano, chap. 14 of Power, J.A., Coombs, M.L., and Freymueller, J.T., eds., The 2006 eruption of Augustine Volcano, Alaska: U.S. Geological Survey Professional Paper 1769, p. 321-332. (Also available at http://pubs.usgs.gov/pp/1769/.)

Reid, M.E., Keith, T.E.C., Kayen, R.E., Iverson, N.R., Iverson, R.M., and Brien, D.L., 2010, Volcano collapse promoted by progressive strength reduction-New data from Mount St. Helens: Bulletin of Volcanology, v. 72, p. 761-766. 
Robbins, S.D., 2010, Active volcanoes of Kamchatka and northern Kurile Islands: Alaska Division of Geological and Geophysical Surveys Miscellaneous Publication 137, 3 plates, scale 1:2,000,000 and 1:3,500,000, accessed July 25, 2012, at http://www.dggs.dnr.state.ak.us/pubs/id/21141.

Robinson, J.E., Sisson, T.W., and Swinney, D.D., 2010, Digital topographic map showing the extents of glacial ice and perennial snowfields at Mount Rainier, Washington, based on the LiDAR survey of September 2007 to October 2008: U.S. Geological Survey Data Series 549, data files, available at http://pubs.usgs.gov/ds/549/.

Salerno, G.G., Oppenheimer, C., Tsanev, V.I., Sutton, A.J., Roberts, T.J., and Elias, T., 2010, Enhancement of the volcanogenic "bromine explosion" via reactive nitrogen chemistry (Kîlauea Volcano, Hawai ‘i): Atmospheric Chemistry and Physics Discussions, v. 10, p. 10313-10334.

Schiff, C.J., Kaufman, D.S., Wallace, K.L., and Ketterer, M.E., 2010, An improved proximal tephrochronology for Redoubt Volcano, Alaska: Journal of Volcanology and Geothermal Research, v. 193, p. 203-214.

Schiffman, Peter, Zierenberg, Robert, Chadwick, W.W., Jr., Clague, D.A., and Lowenstern, Jacob, 2010, Contamination of basaltic lava by seawater: evidence found in a lava pillar from Axial Seamount, Juan de Fuca Ridge: Geochemistry Geophysics Geosystems, v. 11, Q04004, 12 p., doi:10.1029/2009GC003009.

Scott, W.E., Nye, C.J., Waythomas, C.F., and Neal, C.A., 2010, August 2008 eruption of Kasatochi Volcano, Aleutian Islands, Alaska-Resetting an island landscape, in Special section-Impacts of the 2008 volcanic eruption on the terrestrial and nearshore marine ecosystems of Kasatochi Island, Alaska: Arctic, Antarctic, and Alpine Research, v. 42, p. 250-259.

Sentman, D.D., McNutt, S.R., Stenbaek-Nielsen, H.C., Tytgat, Guy, and DeRoin, Nicole, 2010, Imaging observations of thermal emissions from Augustine Volcano using a small astronomical camera, chap. 24 of Power, J.A., Coombs, M.L., and Freymueller, J.T., eds., The 2006 eruption of Augustine Volcano, Alaska: U.S. Geological Survey Professional Paper 1769, p. 569-577. (Also available at http://pubs.usgs.gov/pp/1769/.)

Syracuse, E.M., Thurber, C.H., Wolfe, C.J., Okubo, P.G., Foster, J.H., and Brooks, B.A., 2010, High-resolution locations of triggered earthquakes and tomographic imaging of Kilauea Volcano's south flank: Journal of Geophysical Research, v. 115, B10310, 12 p., doi:10.1029/2010JB007554.

Taira, T., Smith, R.B., and Chang, W.-L., 2010, Seismic evidence for dilatational source deformations accompanying the 2004-2008 Yellowstone accelerated uplift episode: Journal of Geophysical Research, v. 115, B02301, 16 p., doi:10.1029/2008JB006281. Talbot, S.S., Talbot, S.L., and Walker, L.R., 2010, Post-eruption legacy effects and their implications for long-term recovery of the vegetation on Kasatochi Island, Alaska, in Special section-Impacts of the 2008 volcanic eruption on the terrestrial and nearshore marine ecosystems of Kasatochi Island, Alaska: Arctic, Antarctic, and Alpine Research, v. 42, p. 285-296.

Thelen, W.A., Malone, S.D., and West, M.E., 2010, Repose time and cumulative moment magnitude - A new tool for forecasting eruptions?: Geophysical Research Letters, v. 37, L18301, 5 p., doi:10.1029/2010GL044194. 
Thelen, Weston, West, Michael, and Senyukov, Sergey, 2010, Seismic characterizations of the fall 2007 eruptive sequence at Bezymianny Volcano, Russia: Journal of Volcanology and Geothermal Research, v. 194, p. 201-213.

Thomas, R.J., McNutt, S.R., Krehbiel, P.R., Rison, William, Aulich, Grayden, Edens, H.E., Tytgat, Guy, and Clark, Edward, 2010, Lightning and electrical activity during the 2006 eruption of Augustine Volcano, chap. 25 of Power, J.A., Coombs, M.L., and Freymueller, J.T., eds., The 2006 eruption of Augustine Volcano, Alaska: U.S. Geological Survey Professional Paper 1769, p. 579-608. (Also available at http://pubs.usgs.gov/pp/1769/.)

Thompson, Glenn, and West, M.E., 2010, Real-time detection of earthquake swarms at Redoubt Volcano, 2009: Seismological Research Letters, v. 81, p. 505-513.

Tilling, R.I., 2010, Scientific and emergency-management response to the 1980 eruptions of Mount St. Helens, Washington-Successful but imperfect: International Workshop on Strategy of Volcanic Disaster Mitigation 2009, November 4-6, 2009, Tsukuba, Japan, Workshop Proceedings 21, p. 2-16.

Tilling, R.I., Heliker, Christina, and Swanson D.A., 2010, Eruptions of Hawaiian volcanoes; past, present, and future: U.S. Geological Survey General Information Product 117, 63 p. (Also available at http://pubs.usgs.gov/gip/117/.)

Turner, Simon, Sandiford, Mike, Reagan, Mark, Hawkesworth, Chris, and Hildreth, Wes, 2010, Origins of large-volume, compositionally zoned volcanic eruptions- $-\mathrm{New}$ constraints from U-series isotopes and numerical thermal modeling for the 1912 Katmai-Novarupta eruption: Journal of Geophysical Research, v. 115, B12201, 22 p., doi:10.1029/2009JB007195.

Vallance, J.W., Bull, K.F., and Coombs, M.L., 2010, Pyroclastic flows, lahars, and mixed avalanches generated during the 2006 eruption of Augustine Volcano, chap. 10 of Power, J.A., Coombs, M.L., and Freymueller, J.T., eds., The 2006 eruption of Augustine Volcano, Alaska: U.S. Geological Survey Professional Paper 1769, p. 219267. (Also available at http://pubs.usgs.gov/pp/1769/.)

Vallance, J.W., Gardner, C.A., Scott, W.E., Iverson, R.M., and Pierson, T.C., 2010, Mount St. Helens - A 30-year legacy of volcanism: Eos Transactions of the American Geophysical Union, v. 91, p. 169-171.

van Manen, S.M., Dehn, J., and Blake, S., 2010, Satellite thermal observations of the Bezymianny lava dome 1993-2008: Precursory activity, large explosions, and dome growth: Journal of Geophysical Research, v. 115, B08205, 20 p., doi:10.1029/2009JB006966.

van Manen, S.M., Dehn, Jonathan, West, M.E., Blake Stephen, and Rothery, D.A., 2010, The 2006 eruption of Augustine Volcano; combined analyses of thermal satellite data and reduced displacement, chap. 23 of Power, J.A., Coombs, M.L., and Freymueller, J.T., eds., The 2006 eruption of Augustine Volcano, Alaska: U.S. Geological Survey Professional Paper 1769, p. 553-567. (Also available at http://pubs.usgs.gov/pp/1769/.)

Vaughan, R.G., Keszthelyi, L.P., Davies, A.G., Schneider, D.J., Jaworowski, Cheryl, and Heasler, Henry, 2010, Exploring the limits of sub-pixel thermal features using ASTER TIR data: Journal of Volcanology and Geothermal Research, v. 189, p. 225-237.

Venezky, Dina, and Wessells, Stephen, 2010, Caldera demonstration model: U.S.

Geological Survey Open-File Report 2010-1173, video, available at http://pubs.usgs.gov/of/2010/1173/. 
Venezky, Dina, and Wessells, Stephen, 2010, Carbon dioxide dangers demonstration model: U.S. Geological Survey Open-File Report 2010-1174, video, available at http://pubs.usgs.gov/of/2010/1174/.

Waitt, R.B., 2010, Ejecta and landslides from Augustine Volcano before 2006, chap. 13 of Power, J.A., Coombs, M.L., and Freymueller, J.T., eds., The 2006 eruption of Augustine Volcano, Alaska: U.S. Geological Survey Professional Paper 1769, p. $297-$ 319. (Also available at http://pubs.usgs.gov/pp/1769/.)

Walder, J.S., 2010, Röthlisberger channel theory-Its origins and consequences: Journal of Glaciology, v. 56, no. 200, p. 1079-1086.

Walder, J.S, Schilling, S.P., Sherrod, D.R., and Vallance, J.W., 2010, Evolution of Crater Glacier, Mount St. Helens, Washington, September 2006-November 2009: U.S. Geological Survey Open-File Report 2010-1141, 34 p., animation, available at http://pubs.usgs.gov/of/2010/1141/.

Wallace, K.L., Neal, C.A., and McGimsey, R.G., 2010, Timing, distribution, and character of tephra fall from the 2005-2006 eruption of Augustine Volcano, chap. 9 of Power, J.A., Coombs, M.L., and Freymueller, J.T., eds., The 2006 eruption of Augustine Volcano, Alaska: U.S. Geological Survey Professional Paper 1769, p. 187-217. (Also available at http://pubs.usgs.gov/pp/1769/.)

Wang, Bronwen, Michaelson, Gary, Ping, Chien-Lu, Plumlee, Geoffrey, and Hageman, Philip, 2010, Characterization of pyroclastic deposits and pre-eruptive soils following the 2008 eruption of Kasatochi Island volcano, Alaska, in Special section-Impacts of the 2008 volcanic eruption on the terrestrial and nearshore marine ecosystems of Kasatochi Island, Alaska: Arctic, Antarctic, and Alpine Research, v. 42, p. 276-284.

Washington Military Department, U.S. Geological Survey, National Tsunami Hazard Mitigation Program, and Washington State Department of Natural Resources, 2010, Media guidebook for natural hazards in Washington-Tsunami and volcano hazards: Washington Military Department, Emergency Management Division, 92 p., accessed July 25, 2012, at http://www.emd.wa.gov/hazards/documents/ MediaTsunamiVolcanoGuidebook.pdf.

Waythomas, C.F., Scott, W.E., and Nye, C.J., 2010, The geomorphology of an Aleutian volcano following a major eruption-The 7-8 August 2008 eruption of Kasatochi Volcano, Alaska, and its aftermath, in Special section-Impacts of the 2008 volcanic eruption on the terrestrial and nearshore marine ecosystems of Kasatochi Island, Alaska: Arctic, Antarctic, and Alpine Research, v. 42, p. 260-275.

Waythomas, C.F., Scott, W.E., Prejean, S.G., Schneider, D.J., Izbekov, Pavel, and Nye, C.J., 2010, The 7-8 August 2008 eruption of Kasatochi Volcano, central Aleutian Islands, Alaska: Journal of Geophysical Research, v. 115, B00B06, 23 p., doi:10.1029/2010JB007437.

Webley, P.W., Dean, K.G., Dehn, Jonathan, Bailey, J.E., and Peterson, Rorik, 2010, Volcanic-ash dispersion modeling of the 2006 eruption of Augustine Volcano using the Puff model, chap. 21 of Power, J.A., Coombs, M.L., and Freymueller, J.T., eds., The 2006 eruption of Augustine Volcano, Alaska: U.S. Geological Survey Professional Paper 1769, p. 507-526. (Also available at http://pubs.usgs.gov/pp/1769/.) 
Webster, J.D., Mandeville, C.W., Goldoff, Beth, Coombs, M.L., and Tappen, Christine, 2010, Augustine Volcano-The influence of volatile components in magmas erupted A.D. 2006 to 2,100 years before present, chap. 16 of Power, J.A., Coombs, M.L., and Freymueller, J.T., eds., The 2006 eruption of Augustine Volcano, Alaska: U.S. Geological Survey Professional Paper 1769, p. 383-423. (Also available at http://pubs.usgs.gov/pp/1769/.)

Wessels, R.L., Coombs, M.L., Schneider, D.J., Dehn, Jonathan, and Ramsey, M.S., 2010, High-resolution satellite and airborne thermal infrared imaging of the 2006 eruption of Augustine Volcano, chap. 22 of Power, J.A., Coombs, M.L., and Freymueller, J.T., eds., The 2006 eruption of Augustine Volcano, Alaska: U.S. Geological Survey Professional Paper 1769, p. 527-552. (Also available at http://pubs.usgs.gov/pp/1769/.)

Wessells, S.M., 2010, Mount St. Helens May 18, 1980: U.S. Geological Survey, video, available at http://gallery.usgs.gov/videos/234.

Wessells, S.M., 2010, Mount St. Helens - A catalyst for change: U.S. Geological Survey, video, available at http://gallery.usgs.gov/videos/235.

Wong, L.J., and Larsen, J.F., 2010, The Middle Scoria sequence-A Holocene violent strombolian, subplinian, and phreatomagmatic eruption of Okmok volcano, Alaska: Bulletin of Volcanology, v. 72, p. 17-31.

Wynn, J.C., 2010, EM and MT methods for volcanic edifice stability and volcanic eruption prediction: Proceedings Volume, Workshop on Electromagnetic Studies of Earthquakes and Volcanoes, October 3-6, 2010: Orange, California, Chapman University, p. 960-985.

Yamada, Takuji, Okubo, P.G., and Wolfe, C.J., 2010, Kīholo Bay, Hawai'i, earthquake sequence of 2006: Relationship of the main shock slip with locations and source parameters of aftershocks: Journal of Geophysical Research, v. 115, B08304, 12 p., doi:10.1029/2009JB006657.

Yellowstone Volcano Observatory, 2010, Protocols for geologic hazards response by the Yellowstone Volcano Observatory: U.S. Geological Survey Circular 1351, 18 p. (Also available at http://pubs.usgs.gov/circ/1351/.)

Zimmer, M.H., Plank, Terry, Hauri, E.H., Yogodzinski, G.M., Stelling, Peter, Larsen, Jessica, Singer, Brad, Jicha, Brian, Mandeville, Charles, and Nye, C.J., 2010, The role of water in generating the calc-alkaline trend-New volatile data for Aleutian magmas and a new tholeiitic index: Journal of Petrology, v. 51, p. 2411-2444. 